\title{
ANALISIS PEMBIAYAAN NON-ANGGARAN PEMERINTAH DALAM MENDUKUNG PEMBANGUNAN INFRASTRUKTUR DI INDONESIA
}

\author{
(Analysis of Non-Government Budget Financing In Supporting Infrastructure \\ Development In Indonesia) \\ Nanda Cahyani Putri ${ }^{1}$, Loveani Yastika Putri ${ }^{2}$ \\ ${ }^{1}$ Magister Perencanaan Wilayah dan Kota, Universitas Diponegoro \\ ${ }^{2}$ Departemen Perencanaan Wilayah dan Kota, Universitas Diponegoro \\ E-mail: nandacahyanip@gmail.com
}

Diterima 25 Februari 2020, Disetujui 30 September 2020

\begin{abstract}
ABSTRAK
Sesuai amanat Rencana Pembangunan Jangka Menengah Nasional (RPJMN) 2020-2024, infrastruktur menjadi salah satu prioritas pembangunan nasional yang bertujuan untuk pengembangan ekonomi dan pelayanan dasar. Pembangunan infrastruktur memerlukan pembiayaan yang tidak sedikit sedangkan anggaran pemerintah sangat terbatas. Hal ini menjadi salah satu kendala pemerintah, baik pemerintah pusat maupun daerah, untuk melakukan pembangunan infrastruktur secara merata. Pemerintah perlu mengembangkan gagasan/inovasi pembiayaan melalui instrumen rencana pembangunan infrastruktur untuk memenuhi kebutuhan finansial dalam meningkatkan pelayanan infrastruktur. Salah satunya adalah dengan menerapkan skema pembiayaan non-anggaran pemerintah. Penelitian ini bertujuan untuk menganalisis peluang skema pembiayaan infrastruktur non-anggaran pemerintah yang sesuai untuk diterapkan di Indonesia. Penelitian ini menggunakan metode skoring berdasarkan kriteria yang disusun melalui kajian literatur. Pengumpulan data dilakukan dengan melakukan wawancara dengan pemangku kepentingan yang relevan. Berdasarkan hasil analisis, diketahui empat skema yang sangat berpotensi untuk dikembangkan di Indonesia, antara lain konsolidasi lahan, pinjaman daerah, obligasi, dan Kerjasama Pemerintah dan Badan Usaha (KPBU).
\end{abstract}

Kata Kunci: Infrastruktur, Pembiayaan Pembangunan, Skema Pembiayaan, Non-Anggaran Pemerintah

\begin{abstract}
Infrastructure development is one of the national development priorities in the National Medium-Term Development Plan (RPJMN) 2020-2024 aimed to improve the economic condition and provide basic services. One of the challenges of providing good-quality infrastructure is the need for a huge amount of budget while the government's financial capacity is very limited. Accordingly, developing sufficient infrastructure across the country has become a crucial problem for central, regional, and local governments. The government should create innovation for the infrastructure financing mechanism by using the non-government budgeting scheme. This study aims to analyze the scheme of non-government budgeting that is suitable in Indonesia. The analysis uses a scoring method based on criteria compiled from the literature. Interviews with relevant stakeholders were applied to examining the scoring analysis. The result shows that there are four potential schemes to be developed in Indonesia, which are land consolidation, loans, bonds, and Public-Private Partnership (PPP).
\end{abstract}

Keywords: Infrastructure, Development Financing, Financing Schemes, Non-Government Budget Financing 


\section{PENDAHULUAN}

Penyediaan infrastruktur yang efektif, efisien serta berkelanjutan merupakan faktor pandorong pertumbuhan dan pemerataan ekonomi (Chen \& Bartle, 2017). Penyediaan infrastruktur merupakan salah satu prioritas pembangunan nasional yang tertuang dalam Rencana Pembangunan Jangka Menengah Nasional (RPJMN) 2020-2024 yang bertujuan untuk meningkatkan perekonomian serta pelayanan dasar. Pembangunan infrastruktur menjadi pekerjaan rumah yang cukup berat bagi pemerintah seiring berkembangnya fenomena urbanisasi. UNFPA (2007) memprediksi pada tahun 2030 sebanyak 4,9 miliar orang di dunia akan tinggal di kawasan perkotaan, yang berdampak pada peningkatan jumlah permintaan terhadap pelayanan infrastruktur perkotaan. Untuk itu pemerintah sedang gencar malaksanakan pembangunan infrastruktur sebagai salah satu instrumen pembangunan kota yang berkelanjutan.

Sejak pemberlakuan otonomi daerah di Indonesia, pemerintah daerah berhak mengatur dan mengembangkan wilayah otonominya sesuai dengan potensi serta sumber daya yang dimiliki. Salah satu konsep dari otonomi daerah ialah desentralisasi yang memiliki pengertian sebagai penyerahan wewenang dari pemerintah pusat kepada pemerintah daerah untuk melaksanakan pembangunan sesuai dengan aspirasi masyarakat (Ali, Kirmizi, \& Desita, 2015). Istilah dan konsep ini tertuang dalam Bab VI Undang-Undang Dasar 1945 tentang pemerintah daerah serta pelaksanaannya diatur dalam Undang-Undang Nomor 23 Tahun 2014 tentang Pemerintahan Daerah. Undang-Undang No 23 Tahun 2014 mengatur pembagian peran dan kewenangan antara pemerintah pusat, pemerintah provinsi dan pemerintah daerah dalam pembangunan yan diperkuat dengan Undang-Undang Nomor 33 tahun 2004 tentang Perimbangan Keuangan antara Pemerintah Pusat dan Pemerintah Daerah menjadi titik tolak dimana pemerintah daerah berkewajiban mengatur dan mengelola daerahnya. Pelaksanaan desentralisasi diharapkan dapat meningkatkan kemandiriaan dan kapasitas pemerintah daerah dalam pembangunan dan pengelolaan infrastruktur.

Untuk memenuhi kebutuhan infrastruktur saat ini dan masa yang akan datang dibutuhkan anggaran yang tida sedikit. Hal ini menyebabkan sebagian besar pemerintah daerah mengalami kendala keuangan dimana pemerintah daerah masih mengandalkan APBD khususnya dari transfer APBN. Wakil Kementrian Keuangan dikutip dalam Tempo.com menyebutkan tahun 2019 terjadi peningkatan transfer APBN untuk pemerintah daerah hingga $\mathrm{Rp} 826,77$ triliun atau setara dengan $38 \%$ dari total APBN yang sebagian besar dialokasikan untuk pembangunan infrastruktur daerah. Walaupun demikian anggaran pemerintah masih belum mencukupi kebutuhan pendanaan infrastruktur. Berdasarkan data dari Kementerian Keuangan tahun 2015-2019 APBD dan APBN hanya dapat menyerap 41,3 \% kebutuhan pembiayaan infrastruktur. Untuk memenuhi kebutuhan pendanaan infrastruktur terdapat partisipasi dari BUMN sebesar $22,2 \%$ dan swasta sebesar 36,5\%. Dikutip dari laman amp.kontan.co.id tanggal 24 Juli 2019, Badan Perencanaan Pembangunan Nasional (Bappenas) menyebutkan bahwa kemampuan pemerintah Indonesia untuk mendanai pembangunan infrastruktur tahun 2020-2024 diperkirakan hanya sekitar 25\% dari seluruh kebutuhan pembangunan. Untuk itu dibutuhkan alternatif sumber pembiayaan infrastruktur non pemerintah dalam memenuhi kebutuhan pembiayaan.

Hirawan (1995) di dalam penelitiannya menyatakan masih ada sumber-sumber pembiayaan lain yang dapat dimanfaatkan sebagai alternatif pembiayaan pembangunan. Sumber tersebut berasal dari swasta/privat ataupun melalui kolaborasi antara pemerintah dengan swasta. Pendapat ini kemudian dilengkapi Artiningsih, et al (2019), yakni menyatakan bahwa sumber pembiayaan infrastruktur juga dapat bersumber dari masyarakat. Sumber-sumber pembiayaan tersebut dikenal sebagai pembiayaan non-konvensional atau selanjutnya disebut sebagai pembiayaan non-anggaran pemerintah. Meskipun demikian, pemerintah telah menyadari dan mencoba mengembangkan pembiayaan infrastruktur non-anggaran pemerintah ini ke dalam sebuah skema Kerjasama Pemerintah dan Badan Usaha (KPBU) dan PINA. Akan tetapi pembangunan infrastruktur yang dapat direalisasikan melalui skema ini masih terbatas dan sulit diterapkan di beberapa wilayah Indonesia (Wibowo, 2016). Pemerintah perlu berinovasi dan menemukan alternatif skema pembiayaan lainnya yang tepat sesuai kebutuhan infrastruktur yang ada di Indonesia. Penerapan inovasi ini dapat mengisi kesenjangan antara kebutuhan dengan ketersedian infrastruktur.

Penelitian ini bertujuan untuk menganalisis peluang skema pembiayaan infrastruktur nonanggaran pemerintah yang sesuai untuk diterapkan di Indonesia. Kajian ini mencoba memperkenalkan inovasi pembiayaan infrastruktur non-anggaran pemerintah serta kesesuaian penyelenggaraannya berdasarkan beragam kriteria. Adapun kerangka pemikiran dari penelitian ini diilustrasikan pada Gambar 1. 


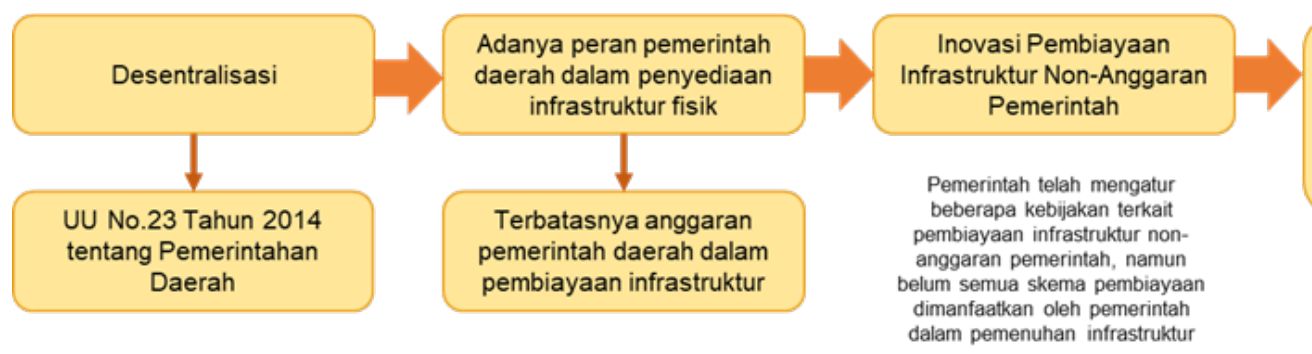

Bagaimana kriteria skema alternatif pembiayaan infrastruktur non-anggaran pemerintah yang cocok dan dapat di terapkan di Indonesia

(a)

imanfaatkan oleh pemerintah

dalam pemenuhan infrastruktur

Gambar 1. Kerangka Pemikiran Penelitian

\section{Skema Pembiayaan Infrastruktur Non- Anggaran Pemerintah}

Seiring dengan perkembangan teknologi serta peningkatan jumlah penduduk, Indonesia sedang dihadapkan dengan tekanan kebutuhan pembangunan yang besar. Pada beberapa tahun terakhir, Indonesia mulai mengenal dengan istilah kerjasama pemerintah dengan swasta, yang saat ini dikenal sebagai Kerjasama Pemerintah dan Badan Usaha (KPBU). Skema kerjasama ini mengadopsi konsep public-private partnership kemudian dikembangkan sebagai salah satu alternatif pembiayaan pembangunan di Indonesia. Dengan berhasilnya penerapan KPBU, kemudian pemerintah melalui Bappenas juga mengembangkan sebuah skema lainnya yang bernama PINA (Pembiayaan Investasi Non Pemerintah). Dari perkembangan inovasi yang terjadi, diketahui bahwa pemerintah dapat melibatkan stakeholder lain diluar pemerintahan untuk berkontribusi dalam pembangunan.

Selain KPBU dan PINA, beberapa penelitian terdahulu telah mengungkapkan jenis-jenis pembiayaan infrastruktur non-anggaran pemerintah. Berdasarkan penelitian yang dilakukan oleh Hirawan (1995) dan Artiningsih, dkk (2019), setidaknya terdapat 14 jenis pembiayaan infrastruktur non-anggaran pemerintah yang sudah pernah dilakukan diseluruh dunia. Jenis-jenis pembiayaan tersebut dibagi kedalam empat mekanisme diantaranya: 1) pendapatan, 2) hutang, 3) kekayaan dan 4) lainnya. Skema pendapatan terdiri dari betterment levies, development impact fees, dan land readjusment. Untuk pembiayaan dengan skema hutang terdiri dari pinjaman daerah, obligasi, development impact exaction, excess condemnation, dan linkage. Skema pembiayaan melalui kekayaan terdiri dari manajemen aset, joint venture, KPBU, dan PINA. Sedangkan skema lainnya terdiri dari CSR dan filantropi. Jenis-jenis ataupun skema pembiayaan di atas belum seluruhnya dikenal dan pernah diterapkan di Indonesia. Skema pembiayaan non pemerintah yang pernah diterapkan di Indonesia dapat dilihat pada Tabel 1.

Dengan adanya beberapa jenis pembiayaan yang tertuang pada Tabel 1, menunjukkan bahwa baik pemerintah pusat maupun daerah telah menyadari pentingnya dukungan stakeholder lain dalam hal pembangunan infrastruktur. Untuk itu pentingnya bagi pemerintah merumuskan alternatif instrumen pembiayaan pembangunan infrastruktur yang strategis dan efisien. Sebelum memanfaatkan skema pembiayaan non-anggaran pemerintah, maka perlu dilakukan penilaian terhadap kriteria pembiayaan pembangunan yang sesuai diterapkan di Indonesia.

\section{Kriteria Pembiayaan Non-Anggaran Pemerintah dalam Pembangunan Infrastruktur}

Jenis pembiayaan non-anggaran pemerintah bertujuan untuk meningkatkan efisiensi dan efektivitas kinerja pemerintah dalam menyediakan infrastruktur, terutama dari segi pembiayaan dan sumber pendanaan. Dalam pembiayaan infrastruktur efisiensi diartikan sebagai sebuah ukuran mengetahui sejauh mana besaran sumber daya yang digunakan dalam mencapai hasil yang disepakati (Oliver, 2013); sedangkan efektivitas dapat diartikan sebagai sejauh mana instrumen dapat memberikan akses yang andal dan memadai secara tepat waktu (Henn, Sloan, Charles, \& Douglas, 2016). Beberapa hal yang diperlukan untuk memilih alternatif yang sesuai dengan kebutuhan pembangunan diantaranya metode yang digunakan, besaran sumber daya yang dikeluarkan dan waktu yang dibutuhkan. Jenis-jenis pembiayaan yang sudah dijelaskan sebelumnya memiliki standar besaran investasi yang berbeda-beda. Artiningsih et., al (2019) dalam penelitiannya, mengaitkan pembiayaan infrastruktur non-konvensional di Kota Semarang kedalam tiga katagori besaran investasi, antara lain investasi rendah, sedang dan tinggi. Besaran investasi rendah sebesar 0-20 Milyar Rupiah; investasi sedang sebesar 20-100 Milyar Rupiah; dan investasi tinggi sebesar lebih dari 100 Milyar Rupiah. Tabel 2 memperlihatkan ilustrasi besaran investasi serta jangka waktu pelaksanaan jenis pembiayaan infrastruktur non-anggaran pemerintah.

Untuk mengukur efektivitas alternatif pembiayaan infrastruktur yang sesuai untuk diterapkan di Indonesia, maka disusunlah beberapa kriteria pembiayaan yang diadopsi dari berbagai penelitian. Terdapat tujuh kriteria yang digunakan dapat dilihat pada Tabel 3. 
Tabel 1. Skema Pembiayaan Non-Anggaran Pemerintah yang Pernah di Terapkan di Indonesia.

\begin{tabular}{|c|c|c|c|c|c|}
\hline Jenis & Defenisi & Sumber & Dasar Hukum & Contoh Pelaksanaan & Keterangan \\
\hline KPBU & $\begin{array}{l}\text { KPBU merupakan salah satu } \\
\text { bentuk pembiayaan public } \\
\text { private partnership yaitu bentuk } \\
\text { kerjasama antara sektor publik } \\
\text { dan swasta dalam pengadaan } \\
\text { infrastruktur publik dengan } \\
\text { menciptakan keuntungan } \\
\text { diantara mitra kerjasama. Di } \\
\text { Indonesia PPP dikenal dengan } \\
\text { nama KPBU }\end{array}$ & $\begin{array}{l}\text { Hodge, Greve, \& } \\
\text { Boardman, (2010) } \\
\text { Grimsey \& Lewis, } \\
(2004)\end{array}$ & $\begin{array}{l}\text { - Peraturan Presiden Republik } \\
\text { Indonesia Nomor 38 Tahun } \\
2015 \text { Tentang Kerjasam } \\
\text { Pemerintah Dengan Badan } \\
\text { Usaha } \\
\text { - Peraturan } \\
\text { Perencanaan Pembangunan } \\
\text { Nasional Nomor 4 Tahun } \\
2015 \text { tentang Tata Cara } \\
\text { Pelaksanaan Kerjasama } \\
\text { Pemerintah Dengan Badan } \\
\text { Usaha Dalam Penyediaan } \\
\text { Infrastruktur }\end{array}$ & $\begin{array}{lcc}\text {-SPAM } & \text { Semarang } & \text { Barat } \\
\text { senilai } & 1,2 & \text { Triliun } \\
\text { (Bappenas, 2018) } & \\
\text { - Jalan Tol Manado-Bitung } \\
\text { senilai } \quad 5,1 & \text { Triliun } \\
\text { (Bappenas, 2018) } & \\
& \end{array}$ & $\begin{array}{l}\text { KPBU memiliki } 4 \\
\text { skema antara lain KPBU } \\
\text { Viability Gap Fund (VGF) } \\
\text { yaitu dengan pemberian } \\
\text { dukungan fiskal oleh } \\
\text { pemerintah, } \\
\text { Availability Payment (AP) } \\
\text { melalui pembayaran berkala } \\
\text { oleh pemerintah kepada } \\
\text { badan usaha, dan KPBU } \\
\text { dukungan sebagian } \\
\text { kontruksi oleh pemerintah. }\end{array}$ \\
\hline PINA & $\begin{array}{l}\text { PINA merupakan salah satu } \\
\text { bentuk public private } \\
\text { partnership. Skema PINA lebih } \\
\text { dikhususkan untuk membiayai } \\
\text { proyek-proyek Infrastruktur } \\
\text { strategis nasional yang } \\
\text { mempunyai nilai komersial. }\end{array}$ & pina.bappenas.go.id & $\begin{array}{l}\text { Menteri PPN/Kepala Bappenas } \\
\text { Nomor 70/M.PPN/HK/12/2016 } \\
\text { tentang Pembentukan Tim } \\
\text { Fasilitasi Pemerintah dalam } \\
\text { Pembiayaan Investasi Non } \\
\text { Anggaran Pemerintah. }\end{array}$ & $\begin{array}{lr}\text { - Pembangkit } & \text { Listrik } \\
\text { Tenaga romassa } & \text { Bioman } \\
\text { (PLTBm) di Kalimantan } \\
\text { Barat senilai 290 Milyar } \\
\text { (Agustine, 2018) } \\
\text { - pembangunan jalan tol } \\
\text { ruas Solo-Yogyakarta- } \\
\text { New rogyakarta } \\
\text { International } r \text { Airport } \\
\text { (NYIA) sepanjang 91,93 } \\
\text { km dengan nilai proyek } \\
22,5 \quad r \text { triliun } \\
\text { (Sukarelawanto, 2018) }\end{array}$ & \\
\hline
\end{tabular}




\begin{tabular}{|c|c|c|c|c|c|}
\hline Jenis & Defenisi & Sumber & Dasar Hukum & Contoh Pelaksanaan & Keterangan \\
\hline \multirow[t]{2}{*}{ CSR } & $\begin{array}{l}\text { CSR merupakan pelaksanaan } \\
\text { kegiatan oleh perusahaan untuk } \\
\text { menciptakan pengakuan publik } \\
\text { terhadap kesadaran dan } \\
\text { kepedulian sosial perusahaan } \\
\text { yang secara tidak langsung } \\
\text { akan memberikan dampak } \\
\text { positif terhadap perusahaan. } \\
\text { Pelaksanaan CSR dilakukan } \\
\text { dalam bentuk sukarela dan } \\
\text { diatur oleh regulasi. }\end{array}$ & Carroll (2009) & $\begin{array}{l}\text { Undang - Undang Nomor } 40 \\
\text { tahun } 2007 \text { tentang Perseroan } \\
\text { Terbatas dan Peraturan } \\
\text { Menteri Negara BUMN No. } \\
\text { PER-05/MBU/2007 tentang } \\
\text { Kegiatan Kemitraan BUMN } \\
\text { Dengan Usaha Kecil dan } \\
\text { Kegiatan Bina Lingkungan. }\end{array}$ & $\begin{array}{l}\text { - perbaikan rumah tidak } \\
\text { layak huni, perbaikan } \\
\text { sanitasi, peningkatan } \\
\text { sumber daya manusia di } \\
\text { Pulau Bangka senilai } 9 \\
\text { milyar (Ferdiansyah, } \\
\text { 2017) dalan di } \\
\text { pembuatan jan } \\
\text { daerah-daerah terpencil } \\
\text { serta pembelian tangki } \\
\text { air bersih dan }\end{array}$ & \\
\hline & & & & $\begin{array}{l}\text { - pembuatan sumur bor di } \\
\text { Kota Makassar senilai } 10 \\
\text { milyar (Bumn.go.id, } \\
\text { 2016) }\end{array}$ & \\
\hline $\begin{array}{l}\text { Pinjaman } \\
\text { Daerah }\end{array}$ & $\begin{array}{l}\text { Pinjaman daerah merupakan } \\
\text { bentuk alternatif pembiayaan } \\
\text { infrastruktur untuk mengatasi } \\
\text { keterbatasan anggaran melalui } \\
\text { pinjaman kepada pemerintah } \\
\text { maupun non pemerintah dalam } \\
\text { bentuk kredit }\end{array}$ & Bahl \& Linn (2002) & 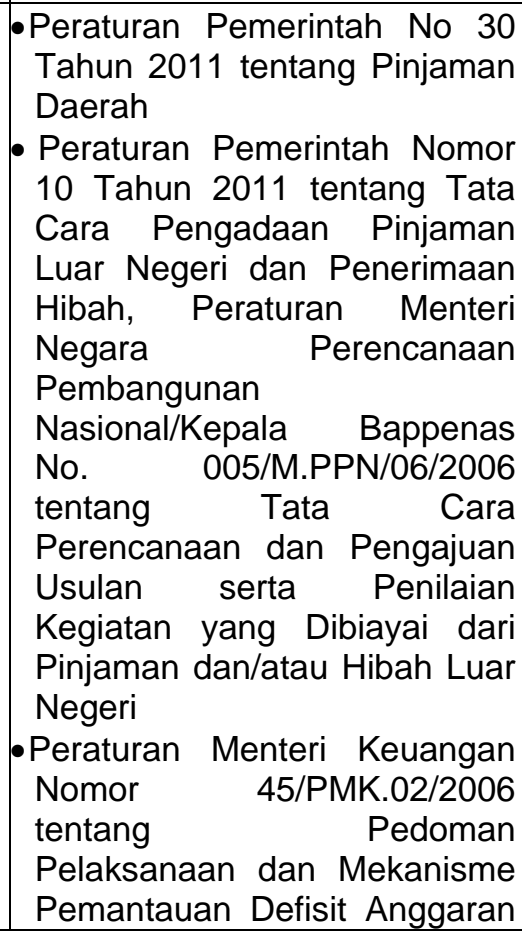 & $\begin{array}{l}\text { - pembangunan } \\
\text { flyover/Underpass, } \\
\text { pelebaran jembatan, dan } \\
\text { peningkatan ruas jalan di } \\
\text { Lampung senilai } 237 \\
\text { Milyar (Adji, 2017) } \\
\text {-pembangunan RSUD } \\
\text { Sanjiwani di Bali senilai } \\
\text { 150 milyar (PT.SMI, } \\
\text { 2016) }\end{array}$ & \\
\hline
\end{tabular}




\begin{tabular}{|c|c|c|c|c|c|}
\hline Jenis & Defenisi & Sumber & Dasar Hukum & Contoh Pelaksanaan & Keterangan \\
\hline & & & $\begin{array}{l}\text { Pendapatan dan Belanja } \\
\text { Daerah dan Pinjaman Daerah }\end{array}$ & & \\
\hline \multirow[t]{2}{*}{ Obligasi } & $\begin{array}{l}\text { Obligasi merupakan surat utang } \\
\text { yang ditawarkan kepada publik } \\
\text { melalui penawaran umum di } \\
\text { pasar modal dan diterbitkan } \\
\text { oleh pemerintah }\end{array}$ & $\begin{array}{l}\text { Okta \& Kaluge, } \\
\text { (2011) }\end{array}$ & $\begin{array}{l}\text {-peraturan pemerintah Nomor } \\
30 \text { Tahun 2011 tentang } \\
\text { Pinjaman Daerah } \\
\text {-PMK Nomor 147/PMK.07/2006 } \\
\text { tentang Tata Cara Penerbitan, } \\
\text { Pertanggungjawaban, dan } \\
\text { Publikasi Infrastruktur Obligasi } \\
\text { Daerah } \\
\text { - Paket Peraturan Ketua } \\
\text { Bapepam-LK terkait dengan } \\
\text { Penawaran Umum Obligasi }\end{array}$ & $\begin{array}{l}\text { tol Trans Sumatera ruas } \\
\text { Bakauheni - Terbanggi } \\
\text { Besar senilai Rp 6,5 } \\
\text { triliun oleh PT Hutama } \\
\text { Karya (Sidik, 2018) }\end{array}$ & \\
\hline & & & $\begin{array}{l}\text { - Daerah (KEP-63/BL/2007, } \\
\text { KEP-64/BL/2007, KEP- } \\
\text { 65/BL/2007, KEP-66/BL/2007, } \\
\text { KEP-67/BL/2007 dan KEP- } \\
\text { 68/BL/2007) }\end{array}$ & & \\
\hline $\begin{array}{l}\text { Manajemen } \\
\text { Aset }\end{array}$ & $\begin{array}{l}\text { Manajemen aset merupakan } \\
\text { upaya mempertahankan, } \\
\text { meningkatkan, dan } \\
\text { mengoperasikan sumber daya } \\
\text { secara efektif dan efisien }\end{array}$ & $\begin{array}{l}\text { McNeil, Tischer, \& } \\
\text { DeBlasio (2000) }\end{array}$ & $\begin{array}{l}\text { Peraturan Pemerintah Republik } \\
\text { Indonesia Nomor } 27 \text { Tahun } \\
2014 \text { Tentang Pengelolaan } \\
\text { barang Milik Negara/Daerah }\end{array}$ & $\begin{array}{lr}\text { penyewaan } & \text { atau } \\
\text { kerjasama pemanfaatan } \\
\text { gedung dan } & \text { lahan } \\
\text { pemerintah } & \text { daerah } \\
\text { kepada swasta } & \end{array}$ & $\begin{array}{l}\text { Manajemen aset merupakan } \\
\text { bentuk pengelolaan atau } \\
\text { pemanfaatan kekayaan milik } \\
\text { daerah. Pelaksanaan } \\
\text { manajemen aset di } \\
\text { Indonesia berupa sewa, } \\
\text { pinjam pakai, kerjasama } \\
\text { pemanfaatan, bangun guna } \\
\text { serah atau bangun serah } \\
\text { guna. }\end{array}$ \\
\hline $\begin{array}{l}\text { Join } \\
\text { Venture }\end{array}$ & $\begin{array}{l}\text { Joint Venture merupakan } \\
\text { pendanaan pelaksanaan proyek } \\
\text { tertentu melalui kemitraan atau } \\
\text { usaha patungan. Pembiayaan } \\
\text { infrastruktur melalui joint } \\
\text { venture juga dapat } \\
\text { dikategorikan sebagai bentuk } \\
\text { kerjasama public private } \\
\text { partnership. Pada pelaksanaan } \\
\text { joint venture terdapat }\end{array}$ & Blaiklock (2014) & $\begin{array}{l}\text { - Undang Undang } \\
\text { Tahun Nomor } 25 \\
\text { Penanaman Modal } \\
\text { - Peraturan Presiden Nomor } 90 \\
\text { Tahun 2007 tentang Badan } \\
\text { Koordinasi Penanaman Modal } \\
\text { - Peraturan Kepala BKPM } \\
\text { Nomor } 7 \text { Tahun } 2010 \\
\text { - Keputusan Menteri Dalam } \\
\text { Negeri dan Otonomi Daerah }\end{array}$ & $\begin{array}{l}\text {-pembangunan rest area } \\
\text { tol Batang - Semarang } \\
\text { dengan nilai investasi } 63 \\
\text { M ((Mughis, 2018) } \\
\text {-PLTS NTB dengan nilai } \\
\text { 1,85 triliun (Hartati, 2016) } \\
\text { - Tol probolinggo- } \\
\text { Banyuwangi senilai 38,1 } \\
\text { triliun (Okezone.com, } \\
\text { 2018) }\end{array}$ & \\
\hline
\end{tabular}


Nanda Cahyani P, Loveani Yastika P

\begin{tabular}{|c|c|c|c|c|c|}
\hline Jenis & Defenisi & Sumber & Dasar Hukum & Contoh Pelaksanaan & Keterangan \\
\hline & $\begin{array}{l}\text { pembagian modal, risiko, dan } \\
\text { keuntungan bersama. }\end{array}$ & & $\begin{array}{l}\text { Nomor } 43 \text { Tahun } 2000 \\
\text { Tentang Pedoman Kerjasama } \\
\text { Perusahaan Daerah dengan } \\
\text { Pihak Ketiga. }\end{array}$ & & \\
\hline $\begin{array}{l}\text { Konsolidasi } \\
\text { Lahan }\end{array}$ & $\begin{array}{l}\text { Konsolidasi lahan merupakan } \\
\text { penataan lahan kembali dan } \\
\text { pengadaan lahan untuk } \\
\text { kepentingan pembangunan } \\
\text { secara partisipatif }\end{array}$ & Sitorus (2015) & $\begin{array}{l}\text { Peraturan Menteri Agraria dan } \\
\text { Tata Ruang/Kepala Badan } \\
\text { Pertanahan Nasional Republik } \\
\text { Indonesia Nomor } 12 \text { Tahun } \\
2019 \text { tentang Konsolidasi lahan }\end{array}$ & $\begin{array}{l}\text { KIP (Kampoong } \\
\text { Improvement Program). } \\
\text { Adapun target dari } \\
\text { kegiatan ini ialah } \\
\text { kepemilikan ruang publik } \\
\text { sebesar } 15-25 \% \text { dan } \\
\text { sisanya adalah ruang } \\
\text { privat dengan luas } \\
\text { pengembalian dari } \\
\text { besaran sebelumnya } \\
\text { adalah } 50-60 \% \text {. }\end{array}$ & $\begin{array}{l}\text { Konsolidasi lahan biasanya } \\
\text { diterapkan pada wilayah } \\
\text { atau kawasan yang belum } \\
\text { berkembang } \\
\text { memiliki namun } \\
\text { kepemilikan lahan yang } \\
\text { lengkap. }\end{array}$ \\
\hline
\end{tabular}


Tabel 2. Skema Pembiayaan Non-Anggaran Pemerintah berdasarkan besaran Investasi dan Jangka Waktu Pelaksanaan

\begin{tabular}{|c|c|c|c|c|c|c|}
\hline \multirow{2}{*}{ No } & \multirow{2}{*}{ Mekanisme } & \multirow{2}{*}{ Jenis Pembiayaan } & \multicolumn{3}{|c|}{ Besaran Investasi } & \multirow{2}{*}{$\begin{array}{c}\text { Jangka Waktu } \\
\text { Pelaksanaan }\end{array}$} \\
\hline & & & Rendah & Sedang & Tinggi & \\
\hline 1 & \multirow{3}{*}{ Pendapatan } & Betterment Levies & & & & Jangka Pendek \\
\hline 2 & & $\begin{array}{l}\text { Development Impact } \\
\text { Fees }\end{array}$ & & & & Jangka Pendek \\
\hline 3 & & Land Readjustment & & & & Jangka Pendek \\
\hline 4 & \multirow{5}{*}{ Hutang } & Pinjaman Daerah & & & & $\begin{array}{l}\text { Jangka Menengah, } \\
\text { Jangka Panjang }\end{array}$ \\
\hline 5 & & Obligasi & & & & $\begin{array}{l}\text { Jangka Menengah } \\
\text { Jangka Panjang }\end{array}$ \\
\hline 6 & & $\begin{array}{l}\text { Development } \\
\text { Exactions }\end{array}$ & & & & Jangka Panjang \\
\hline 7 & & Excess Condemnation & & & & Jangka Panjang \\
\hline 8 & & Linkage & & & & Jangka Panjang \\
\hline 9 & \multirow{4}{*}{ Kekayaan } & Manajemen Aset & & & & $\begin{array}{l}\text { Jangka Pendek } \\
\text { Jangka Menengah }\end{array}$ \\
\hline 10 & & Join Venture & & & & Jangka Panjang \\
\hline 11 & & KPBU & & & & Jangka Panjang \\
\hline 12 & & PINA & & & & Jangka Panjang \\
\hline 13 & \multirow{2}{*}{ Lainnya } & CSR & & & & Jangka Pendek \\
\hline 14 & & Filantropi & & & & Jangka Pendek \\
\hline
\end{tabular}

Sumber: (Artiningsih, et.,al 2019) diolah oleh penulis

Tabel 3. Kriteria Skema Pembiayaan Infrastruktur Non-Anggaran Pemerintah

\begin{tabular}{|c|c|c|c|}
\hline Kriteria & Definisi & Sumber & Keterangan \\
\hline $\begin{array}{l}\text { Ketersediaan } \\
\text { Regulasi }\end{array}$ & $\begin{array}{lr}\text { Ketersediaan regulasi berupa } \\
\text { undang-undang r dan } \\
\text { peraturan terkait } \\
\text { skema pembiayaan }\end{array}$ & $\begin{array}{l}\text { Kurniawan, } \\
\text { Salman, } \\
\text { Agustin, \& } \\
\text { Pratidina, } \\
\text { (2017) }\end{array}$ & $\begin{array}{l}\text { Ketersediaan regulasi akan } \\
\text { memberikan kepastian hukum dan } \\
\text { meminimalisisr risiko hukum bagi } \\
\text { swata sehingga mempengaruhi } \\
\text { kesediaan investor untuk membiayai } \\
\text { proyek }\end{array}$ \\
\hline $\begin{array}{l}\text { Historis } \\
\text { pelaksanaan }\end{array}$ & $\begin{array}{lr}\text { Data historis } & \text { pelaksanaan } \\
\text { pembiayaan } & \text { berupa } \\
\text { implementasi } & \text { skema } \\
\text { pembiyaan yang telah } \\
\text { diterapkan sebelumnya }\end{array}$ & $\begin{array}{l}\text { Henn et al., } \\
(2015)\end{array}$ & $\begin{array}{l}\text { Pemilihan instrumen pembiayaan } \\
\text { merupakan bentuk upaya } \\
\text { memperbaiki kesalahan pelaksanaan } \\
\text { investasi sebelumnya }\end{array}$ \\
\hline $\begin{array}{l}\text { Risiko } \\
\text { Pelaksanaan }\end{array}$ & $\begin{array}{l}\text { Risiko merupakan } \\
\text { konsekuensi yang dapat } \\
\text { menimbulkan kerugian dalam } \\
\text { pelaksanaan pembiayaan. } \\
\text { Risiko dapat meliputi risiko } \\
\text { kontruksi, operasi, teknis, } \\
\text { sosial, lingkungan, finansial, } \\
\text { hukum dan politik }\end{array}$ & $\begin{array}{l}\text { Ehlers } \\
(2014) \\
\text { Blaiklock } \\
(2014)\end{array}$ & $\begin{array}{l}\text { - Diversifikasi risiko yang lebih besar } \\
\text { dari jenis pembiayaan kegiatan } \\
\text { infrastruktur lebih menarik investror } \\
\text { - Risiko dapat terdistribusi secara } \\
\text { optimal kepada pihak yang mampu } \\
\text { mengelola risiko }\end{array}$ \\
\hline $\begin{array}{l}\text { Keberlanjutan } \\
\text { manfaat }\end{array}$ & $\begin{array}{lr}\text { Keberlanjutan } & \text { manfaat } \\
\text { merupakan dampak jangka } \\
\text { panjang yang ditimbulkan } \\
\text { dalam } & \text { pelaksanaan } \\
\text { pembiayaan } & \text { proyek } \\
\text { infrastruktur } & \\
\end{array}$ & $\begin{array}{l}\text { Wellman } \\
\text { Spiller } \\
(2012)\end{array}$ & $\begin{array}{l}\text { Instrumen pembiayaan yang } \\
\text { mendukung keberlanjutan manfaat } \\
\text { yang tinggi lebih potensial untuk } \\
\text { diterapkan dalam membiayai proyek } \\
\text { infrastruktur. }\end{array}$ \\
\hline $\begin{array}{l}\text { Manfaat sosial } \\
\text { ekonomi }\end{array}$ & 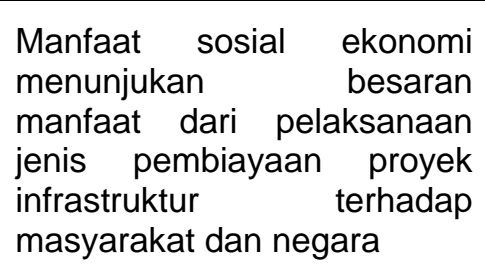 & $\begin{array}{l}\text { Wellman } \\
\text { Spiller } \\
(2012)\end{array}$ & $\begin{array}{l}\text { Manfaat ekonomi yang dihasilkan } \\
\text { oleh investasi infrastruktur dapat } \\
\text { berkelanjutan dan signifikan } \\
\text { sehingga kesejahteraan masyarakat } \\
\text { dapat meningkat }\end{array}$ \\
\hline
\end{tabular}




\begin{tabular}{l|l|l|l}
\hline Kriteria & \multicolumn{1}{|c|}{ Definisi Sumber } & \multicolumn{1}{c}{ Keterangan } \\
\hline Manfaat finansial & $\begin{array}{l}\text { Manfaat finansial berupa } \\
\text { keuntungan finansial yang } \\
\text { didapatkan oleh pemerintah } \\
\text { maupun swasta }\end{array}$ & $\begin{array}{l}\text { Henn et al., } \\
(2015)\end{array}$ & $\begin{array}{l}\text { Pelibatan swasta dalam pelaksanan } \\
\text { kegiatan setidaknya harus memenuhi } \\
\text { tingkat minimum pengembalian } \\
\text { proyek bagi investor }\end{array}$ \\
\hline $\begin{array}{l}\text { Daya ungkit } \\
\text { terhadap } \\
\text { pembangunan }\end{array}$ & $\begin{array}{l}\text { Daya ungkit dapat dilihat dari } \\
\text { peningkatan kapasitas suatu } \\
\text { daerah berupa peningkatan } \\
\text { jumlah sumber daya dan } \\
\text { produktivitas sumber daya } \\
\text { yang ada }\end{array}$ & $\begin{array}{l}\text { Henn et al., } \\
(2015)\end{array}$ & $\begin{array}{l}\text { Upaya peningkatan pelayanan } \\
\text { infrastruktur dapat mengoptimalkan } \\
\text { daya ungkit terhadap pembangunan }\end{array}$ \\
\hline
\end{tabular}

\section{METODE}

Penelitian ini disusun pada Januari 2020 dengan menggunakan analisis skoring yang disusun berdasarkan kriteria pembiayaan infrastruktur non-anggaran pemerintah. Pengumpulan informasi serta literasi disusun sejalan dengan kajian yang dilakukan bidang Litbang - BAPPEDA Kota Semarang yang berjudul "Kajian Potensi Pembiayaan Infrastruktur Non-Konvensional (Non-Pemerintah) di Kota Semarang pada tahun 2019. Setelah informasi terkumpul, dilakukan verifikasi melalui metode wawancara untuk menentukan kriteria pembiayaan infrastruktur yang sesuai dengan kondisi di Indonesia. Narasumber berasal dari latar belakang yang berbeda yakni, akademisi (Universitas Diponegoro) serta pemerintah pusat (Kemeterian Pekerjaan Umum dan Perumahan Rakyat). Wawancara dilakukan berulang bertujuan untuk mendapatkan hasil skoring yang lebih akurat dan disepakati oleh narasumber.

Analisis skoring disusun berdasarkan tujuh kriteria yang sudah dijabarkan pada tabel 3. Kriteria di susun menggunakan kode abjad dan dinilai berdasarkan kesesuaiannya di Indonesia. Hasil skoring kemudian dijumlah, sehingga diketahui skema pembiayaan apa saja yang berpeluang besar untuk dikembangkan di Indonesia. Penjelasan tiap skor pada masing-masing kriteria yang digunakan dapat dilihat pada Tabel 4.

Tabel 4. Penilaian Kriteria Pembiayaan Infrastruktur Non-Anggaran Pemerintah

\begin{tabular}{|c|c|c|c|c|}
\hline \multirow[t]{2}{*}{ Kode } & \multirow{2}{*}{ Kriteria } & \multicolumn{3}{|c|}{ Skor } \\
\hline & & 1 & 2 & 3 \\
\hline A & $\begin{array}{l}\text { Ketersediaan } \\
\text { regulasi }\end{array}$ & $\begin{array}{l}\text { Regulasi belum } \\
\text { tersedia atau tidak } \\
\text { memadai }\end{array}$ & $\begin{array}{l}\text { Regulasi kurang } \\
\text { memadai atau regulasi } \\
\text { tidak update }\end{array}$ & $\begin{array}{l}\text { Regulasi memadai } \\
\text { dan kuat }\end{array}$ \\
\hline B & $\begin{array}{l}\text { Historis } \\
\text { pelaksanaan }\end{array}$ & $\begin{array}{l}\text { Belum pernah } \\
\text { dilaksanakan di } \\
\text { Indonesia }\end{array}$ & $\begin{array}{l}\text { Telah dilaksanakan } \\
\text { pada sedikit program/ } \\
\text { proyek }\end{array}$ & $\begin{array}{l}\text { Telah dilaksanakan } \\
\text { pada banyak } \\
\text { program/ proyek }\end{array}$ \\
\hline C & $\begin{array}{l}\text { Risiko } \\
\text { pelaksanaan }\end{array}$ & Risiko besar & Risiko sedang & Risiko rendah \\
\hline D & $\begin{array}{l}\text { Keberlanjutan } \\
\text { manfaat }\end{array}$ & $\begin{array}{l}\text { Keberlanjutan } \\
\text { manfaat rendah }\end{array}$ & $\begin{array}{l}\text { keberlanjutan manfaat } \\
\text { sedang }\end{array}$ & $\begin{array}{l}\text { keberlanjutan } \\
\text { manfaat tinggi }\end{array}$ \\
\hline E & $\begin{array}{l}\text { Manfaat sosial } \\
\text { ekonomi }\end{array}$ & $\begin{array}{l}\text { Manfaat sosial } \\
\text { ekonomi rendah }\end{array}$ & $\begin{array}{l}\text { Manfaat sosial } \\
\text { ekonomi sedang }\end{array}$ & $\begin{array}{l}\text { Manfaat sosial } \\
\text { ekonomi besar }\end{array}$ \\
\hline $\mathbf{F}$ & Manfaat finansial & $\begin{array}{l}\text { Manfaat finansial } \\
\text { rendah }\end{array}$ & $\begin{array}{l}\text { Manfaat finansial } \\
\text { sedang }\end{array}$ & $\begin{array}{l}\text { Manfaat finansial } \\
\text { besar }\end{array}$ \\
\hline G & $\begin{array}{l}\text { Daya ungkit } \\
\text { terhadap } \\
\text { Pembangunan }\end{array}$ & $\begin{array}{l}\text { Pengaruh terhadap } \\
\text { daya ungkit } \\
\text { pembangunan } \\
\text { rendah }\end{array}$ & $\begin{array}{l}\text { Pengaruh terhadap } \\
\text { daya ungkit } \\
\text { pembangunan sedang }\end{array}$ & $\begin{array}{l}\text { Pengaruh terhadap } \\
\text { daya ungkit } \\
\text { pembangunan tinggi }\end{array}$ \\
\hline
\end{tabular}

Sumber: (Hasil Analisis, 2020)

\section{HASIL DAN PEMBAHASAN}

Berdasarkan hasil analisis jenis skema atau alternatif pembiayaan infrastruktur non-anggaran pemerintah yang berpeluang untuk di terapkan di Indonesia antara lain Land Readjusment/konsolidasi lahan, Pinjaman Daerah, Obligasi dan KPBU dengan total skor masing-masing skema sebesar 19 . Secara garis besar keempat skema pembiayaan ini berpeluang diterapkan karena jenis pembiayaan ini sudah pernah diterapkan di Indonesia sebelumnya serta memiliki instrumen kebijakan yang cukup jelas. Keempat skema pembiayaan ini memiliki kemiripan kriteria satu sama lain, hanya saja dalam pelaksanaanya memiliki prosedur yang berbeda. Hanya saja, skema pinjaman daerah, obligasi dan KPBU memiliki risiko yang cukup 
besar, karena berkaitan dengan perjanjian kerjasama yang cukup panjang dengan stakeholder lain. Jenis infrastruktur yang dibangun dalam skema ini biasanya berupa infrastruktur dengan investasi skala besar dan mengahasilkan profit, seperti jalan tol, rumah sakit dan sebagainya. Sehingga untuk infrastruktur publik yang tidak menghasilkan profit kurang sesuai untuk diterapkan dengan skema ini.

Tabel 5. Hasil Skoring Pembiayaan Infrastruktur Non-Anggaran Pemerintah

\begin{tabular}{|c|c|c|c|c|c|c|c|c|c|c|}
\hline \multirow{2}{*}{ No } & \multirow{2}{*}{ Mekanisme } & \multirow{2}{*}{ Jenis Pembiayaan } & \multicolumn{7}{|c|}{ Kriteria } & \multirow{2}{*}{$\begin{array}{l}\text { Total } \\
\text { Skor }\end{array}$} \\
\hline & & & A & B & C & D & $E$ & $\mathbf{F}$ & $\mathbf{G}$ & \\
\hline 1 & \multirow{3}{*}{ Pendapatan } & Betterment Levies & 1 & 1 & 2 & 3 & 3 & 3 & 3 & 16 \\
\hline 2 & & Development Impact Fees & 1 & 2 & 1 & 2 & 3 & 2 & 2 & 18 \\
\hline 3 & & Land Readjustment & 3 & 3 & 2 & 3 & 3 & 2 & 3 & 19 \\
\hline 4 & \multirow{5}{*}{ Hutang } & Pinjaman Daerah & 3 & 3 & 1 & 3 & 3 & 3 & 3 & 19 \\
\hline 5 & & Obligasi & 3 & 3 & 1 & 3 & 3 & 3 & 3 & 19 \\
\hline 6 & & Development Exactions & 3 & 1 & 1 & 2 & 2 & 2 & 2 & 13 \\
\hline 7 & & Excess Condemnation & 1 & 1 & 1 & 3 & 2 & 2 & 2 & 12 \\
\hline 8 & & Linkage & 3 & 1 & 2 & 3 & 2 & 2 & 2 & 16 \\
\hline 9 & \multirow{4}{*}{ Kekayaan } & Manajemen Aset & 3 & 3 & 1 & 2 & 2 & 3 & 2 & 16 \\
\hline 10 & & Join Venture & 3 & 2 & 1 & 3 & 2 & 3 & 3 & 16 \\
\hline 11 & & KPBU & 3 & 3 & 1 & 3 & 3 & 3 & 3 & 19 \\
\hline 12 & & PINA & 3 & 2 & 1 & 3 & 3 & 3 & 3 & 18 \\
\hline 13 & \multirow{2}{*}{ Lainnya } & CSR & 3 & 3 & 3 & 2 & 2 & 1 & 2 & 16 \\
\hline 14 & & Filantropi & 1 & 2 & 3 & 2 & 2 & 1 & 2 & 13 \\
\hline
\end{tabular}

Sumber: (Hasil Analisis, 2020)

Selain keempat skema pembiayaan di atas, skema pembiayaan yang berpeluang untuk diterapkan lainnya adalah PINA dan Development Impact Fees dengan total skor 17, serta skema lain yakni Betterment Levies, Linkage, Manajemen Aset, Join Venture dan CSR dengan total skor 16. Join Venture dan PINA merupakan skema pembiayaan infrastruktur skala besar dengan jangka waktu pelaksanaa yang cukup lama seperti halnya dengan KPBU. Akan tetapi PINA dan Join Venture memiliki skor yang lebih rendah dari pada KPBU karena secara historis pelaksanaannya di Indonesia, tidak sebanyak dan dikenal seperti KPBU. Sama halnya dengan KPBU dua mekanisme ini digunakan untuk membangun infrastruktur dengan investasi yang besar sehingga risiko yang kemungkinan terjadi juga semakin besar. Skema lainnya yakni Development Impact Fees (DIF) merupakan skema pembiayaan dengan mekanisme berupa penarikan pungutan kepada swasta atau masyarakat atas dampak dari adanya pembangunan baru (Hirawan, 1995). Disadari atau tidak prosedur seperti ini sudah diterapkan di Indonesia, tepatnya pada pembangunan simpang susun semanggi di Jakarta. Betterment levies juga sudah pernah diterapkan di Jakarta, hanya saja skema ini dianggap gagal karena lemahnya pengawasan dalam penarikan pungutan (Sukarman, 1991). Meskipun demikian skema ini dapat dikembangkan bila terdapat fungsi pengawasan dan regulasi yang tepat.
Skema pembiayaan lainnya yang berpeluang untuk diterapakan antara lain Manajemen aset dan linkage. Di Indonesia skema ini sudah banyak diterapkan, bahkan skema manajemen aset telah memiliki regulasi yang mengatur pelaksanaanya. Hasil dari pemanfaatan aset pemerintah dapat menjadi peluang pemasukan pendapatan yang dapat digunakan untuk pembangunan infrastruktur; sedangan linkage merupakan kewajiban pembangunan kawasan berimbang yang dilakukan oleh developer.

Skema CSR dapat dimanfaatkan pemerintah untuk melakukan pembangunan infrastruktur dengan biaya investasi rendah hingga menengah. Prinsip CSR adalah bentuk tanggung jawab dari perusahaan terhadap kesejahteraan masyarakat. (Nurjanah, Yulianti, Komunikasi, \& Yogyakarta, 2019). Pemerintah dapat melakukan kerjasama dengan perusahaan untuk membangun infrastruktur sesuai dengan kebutuhan dan perencanaan pembangunan yang ada didaerah. Pemanfaatan skema CSR seperti ini tidak menimbulkan risiko yang besar, karena pemerintah, swasta maupun masyarakat mendapatkan manfaat yang seimbang dalam jangka panjang.

Skema pembiayaan lain yang dianggap kurang cocok diterapkan di Indonesia, seperti Development Exactions, Excess Condemnation, dan Filantropi. Akan tetapi Filantropi masih cukup berpeluang untuk diimplementasikan. Dalam 
penelitian Ash-Shiddiqy (2019) wakaf atau kegiatan amal masih dipersepsikan sebagian besar masyarakat sebagai bentuk anjuran keagamaan, bukan sebagai status harta benda yang dapat digunakan untuk kepentingan umum. Filantropi dapat menjadi skema yang sangat berpeluang, apabila dalam pratiknya terdapat regulasi yang mengatur kegiatan sosial/amal kedalam instrumen pembangunan nasional (AshShiddiqy, 2019).

\section{KESIMPULAN}

Berdasarkan hasil analisis, didapatkan empat skema pembiayaan yang berpeluang besar untuk dikembangkan di Indonesia, antara lain konsolidasi lahan, pinjaman daerah, obligasi dan KPBU. Potensi skema pembiayaan lainnya yang dapat dielaborasi antara lain Betterment Levies, Development Impact Fees, Linkage, Manajemen Aset, Join Venture dan PINA. Skema pembiayaan yang dianggap kurang berpeluang untuk diterapkan diantaranya Development Exactions, Excess Condemnation, dan Filantropi. Hasil penelitian ini dapat menjadi pertimbangan atas permasalahan anggaran, dalam bentuk kebijakan publik sebagai dasar hukum pemenuhanan pembangunan infrastruktur di Indonesia. Beberapa skema yang diusulkan dapat dipertimbangkan sesuai potensi tiap daerah dan cakupan wilayah berdasarkan besaran investasi, prosedur pelaksanaan, serta jangka waktu pelaksanaannya.

\section{UCAPAN TERIMA KASIH}

Terima kasih pada dosen-dosen serta rekanrekan Laboratorium Pengembangan Wilayah dan Manajemen Lingkungan, Perencanaan Wilayah dan Kota, Universitas Diponegoro, khususnya kepada Dr-Ing Wiwandari Handayani, ST, MT, MPS yang telah membimbing kami dalam melakukan penelitian dan penyusunan artikel ini. Ucapan terima kasih juga kami sampaikan kepada Dr. Ir Artiningsih, M.Si dari Universitas Diponegoro dan Intan Hasiani Pasaribu, S.PWK dari Direktorat Pelaksanaan Infrastruktur Jalan dan Jembatan, Kementerian Pekerjaan Umum dan Perumahan Rakya sebagai narasumber penelitian ini. Tidak lupa juga, kami ucapan terima kasih kepada Bidang Litbang Bappeda Kota Semarang yang telah membantu dalam proses pengumpulan data dan penyusunan kajian pembiayaan infrastruktur non-anggaran pemerintah di Kota Semarang.

\section{REFERENSI}

Akbar, R., \& Lukman, A. (2010). Manajemen Taman Milik Pemerintah Kota Bandung Berbasiskan Pendekatan Manajemen Aset. Jurnal Teknik Sipil ITB, 17(3), 171-180. https://doi.org/10.5614/jts.2010.17.3.3

Adji, P. S. (2017, May 5). Bangun Flyover, Pemkot Bandarlampung Pinjam Uang Rp237 Miliar. Lampungnews.Com. Retrieved from

https://lampungnews.com/2017/05/bangunflyover-pemkot-bandarlampung-pinjamuang-rp237-miliar/

Agustine, I. (2018, October 13). META Bangun Pembangkit Tenaga Biomassa Sintang Rp290 Miliar. Ekonomi.Bisnis.Com. Retrieved from https://ekonomi.bisnis.com/read/20181013/4 4/848898/meta-bangun-pembangkit-tenagabiomassa-sintang-rp290-miliar

Ali, A., Kirmizi, \& Desita, P. (2015). Analisis Kemampuan Keuangan Daerah Dalam Mendukung Pelaksanaan Otonomi Daerah Kota Pekanbaru (2010 - 2014). Jurnal Online Mahasiswa Fakultas Ekonomi Universitas Riau, 2(1).

Artiningsih, A; Putri, N C; Muktiali, M; Ma'rif, S. (2019). Skema Pembiayaan Pembangunan Infrastruktur Non-Konvensinal di Kota Semarang. Jurnal Riptek. Vol. 13 (2): 92-100

Ash-Shiddiqy, M. (2019). Urgensi Wakaf untuk Kesejahteraan dan Pembangunan. Aplikasia: Jurnal Aplikasi IImu-IImu Agama, 19, 1-9. https://doi.org/.1037//00332909.126.1.78

Bahl, R. W., \& Linn, J. F. (2002). Urban Public Finance in Develepment Countries. New York: Ocford University Press.

Bappenas. (2018). Public-Private Partneships Infrastructure Project Plan In Indonesia.

Bappenas. (2020). Pina is an Enabler: We Facilitate Strategic National Projects Through Creative Financing Scheme. Diakses melalui: http://pina.bappenas.go.id

Blaiklock, M. (2014). Infrastructure Finance Handbook: Principles, Practice and Experience. In Euromoney Books. London: Euromoney Institutional Investor PLC.

Bumn.go.id. (2016). Pelindo IV Akan Salurkan Dana CSR Rp10,25 Miliar Tahun Ini. 
Carroll, A. B. (2009). A History of Corporate Social Responsibility: Concepts and Practices. The Oxford Handbook of Corporate Social Responsibility, (May), 120.

https://doi.org/10.1093/oxfordhb/978019921 1593.003.0002

Chen, C., \& Bartle, J. (2017). Infrastructure financing: A guide for local government managers. ICMA Policy Issue White Paper, 1-35. Retrieved from https://icma.org/documents/infrastructurefinancing-guide-local-government-managers

Ehlers, T. (2014). Understanding the Challenges for Infrastructure Finance. BIS Working Paper, 454.

Ferdiansyah, R. (2017). Samsung Gelontorkan Proyek CSR Senilai Rp9 Miliar di Bangka. Mediaindonesia.Com.

Grimsey, D., \& Lewis, M. K. (2004). The Governance of Contractual Relationships in Public-Private Partnerships. The Journal of Corporate Citizenship, (15), 91-109.

Henn, L., Charles, M. B., Douglas, N., \& Sloan, K. (2015). Debate: Multi-criteria framework needed to assess alternative financing methods for large-scale projects. Public Money and Management, 35(2), 100-102. https://doi.org/10.1080/09540962.2015.1007 703

Hartati, E. R. (2016, April 15). ITDC dan Pertamina Kerjasama Bangun PLTS di Kawasan Mandalika NTB. Beritasatu.Com.

Henn, L., Sloan, K., Charles, M. B., \& Douglas, N. (2016). An appraisal framework for evaluating financing approaches for public infrastructure. Public Money and Management, 36(4), 273-280. https://doi.org/10.1080/09540962.2016.1162 595

Hirawan, S. B. (1995). Pembiayaan Pembangunan Perkotaan melalui Pemanfaatan Instrumen Keuangan.pdf. Jurnal PWK.

Hodge, G. A., Greve, C., \& Boardman, A. E. (2010). Introduction: The PPP Phenomenon and its Evaluation. In International Handbook on Public-Private Partnerships (pp. 3-16). https://doi.org/10.4337/9781849804691.000 08

Kementrian Keuangan. (2018). Pendanaan Infrastruktur. Retrieved from djkn.kemenkeu.go.id website: https://www.djkn.kemenkeu.go.id/berita_med ia/baca/12715/Pendanaan-Infrastruktur.html
Kurniawan, F., Salman, R., Agustin, E., \& Pratidina, I. G. (2017). PENGUATAN MODEL REGULASI DI BIDANG PEMBIAYAAN. Prosiding Simposium IIUNIID, (September), 978-979.

McNeil, S., Tischer, M. L., \& DeBlasio, A. J. (2000). Asset Management: What is the Fuss? Transportation Research Record: Journal of the Transportation Research Board, 1729(1), 21-25. https://doi.org/10.3141/1729-03

Mughis, A. (2018). Rest Area di Jalan Tol Ini Jadi Etalase UMKM. Https://Jatengtoday.Com/.

Nurjanah, A., Yulianti, F., Komunikasi, J. I., \& Yogyakarta, U. M. (2019). Pelaksanaan Program Corporate Sosial Responsibility ( CSR ) dan Komunikasi Csr ( Studi Kasus : CSR Delegation European Union To Malaysia dan dan CSR PT. Holcim Indonesia Tbk. Cilacap Plant). 12(1), 93107.

Okezone.com. (2018, January 5). Menang Proyek Rp38,1 Triliun, Bisnis Jalan Tol Jasa Marga Makin Menggurita. Okezone.Com. Retrieved from https://economy.okezone.com/read/2018/01/ 05/278/1840488/menang-proyek-rp38-1triliun-bisnis-jalan-tol-jasa-marga-makinmenggurita

Oliver, J. (2013). Early Project Appraisal: Making the Initial Choices. Journal of Chemical Information and Modeling, 53(9), 16891699.

https://doi.org/10.1017/СВO9781107415324. 004

Okta, D., \& Kaluge, D. (2011). Analisis Peluang Penerbitan Obligasi Daerah Sebagai Alternatif Pembiayaan Daerah. Journal of Indonesian Applied Economics, 005(02), 157-171. https://doi.org/10.21776/ub/jiae/2016/005.02. 7

PT.SMI. (2016). PT SMI Berikan Pinjaman Rp 150 Miliar untuk Pengembangan RSUD Sanjiwani, Kabupaten Gianyar Provinsi Bali. Retrieved from ptsmi.co.id website: https://ptsmi.co.id/id/siaran-pers/pt-smiberikan-pinjaman-rp-150-miliar-untukpengembangan-rsud-sanjiwani-kabupatengianyar-provinsi-bali/

Republik Indonesia. (2014). Undang-Undang Nomor 23 Tahun 2014 tentang Pemerintahan Daerah

Republik Indonesia. (2020). Perpres Nomor 18 Tahun 2020 tentang Rencana Pembangunan Jangka Menengah Nasional tahun 2020-2024 
Sidik, S. (2018, June 11). Hutama Karya Siapkan Obligasi Bangun 8 Ruas Tol Trans Sumatera. Tribunnews.

Sitorus, O. (2015). Konsolidasi Tanah, Tata Ruang, dan Ketahanan Nasional (1st ed.). Yogyakarta: STPN Press.

Sukarelawanto, E. (2018, October 15). Proyek Jalan Tol: Solo-Bandara Kulonprogo Terhubung 2021. Sumatra.Bisnis. Com.

Sukarman, H. K. (1991). Betterment Levy: An Analysis of The Current Potentian Use of Pajak Khusus Penggantian Biaya dan Pungutan Tambahan di Jakarta, Indonesia. Massachusetts Institute of Technology.
UNFPA. (2007). The State of the World Population 2007 - Unleashing The Potential of Urban Growth. Linking Population, Poverty and Development, 1-34. https://doi.org/ISBN 978-0-89714-807-8

Wellman, K., \& Spiller, M. (2012). Urban Infrastructure: Finance and Management. In K. Wellman (Ed.), Urban Infrastructure: Finance and Management (1st ed.). https://doi.org/10.1002/9781118401637

Wibowo, A. (2016). Perkembangan Terkini Dalam Pembiayaan Infrastruktur Yang Melibatkan Partisipasi Badan Usaha. Konferensi Nasional Teknik Sipil 10, (Oktober), 10. 